\title{
PLA2G4C wt Allele
}

National Cancer Institute

\section{Source}

National Cancer Institute. PLA2G4C wt Allele. NCI Thesaurus. Code C49371.

Human PLA2G4C wild-type allele is located in the vicinity of 19q13.3 and is approximately $63 \mathrm{~kb}$ in length. This allele, which encodes cytosolic phospholipase A2 gamma protein, plays a role in the calcium-independent hydrolysis of phosphatidylcholine. Inherited PLA2G4C polymorphisms are associated with susceptibility to schizophrenia. 